\title{
PEMENUHAN PERSYARATAN STANDAR PENGELOLAAN WISATA SELAM REKREASI
}

\author{
The Fulfillment of Diving Recreational Tourism Management Standard
}

\author{
Ellia Kristiningrum dan Febrian Isharyadi
}

Pusat Penelitian dan Pengembangan Standardisasi, Badan Standardisasi Nasional

Gedung 1 BPPT Lantai 12, Jl. MH. Thamrin No. 8, Kebon Sirih, Jakarta 10340, Indonesia

e-mail: ellia@bsn.go.id

Diterima: 19 Februari 2018, Direvisi: 28 Maret 2018, Disetujui: 2 April 2018

\begin{abstract}
Abstrak
Persyaratan minimal penyelenggaraan usaha wisata selam rekreasi serta pedoman best practices sertifikasi usaha wisata selam rekreasi, diatur dalam standar usaha wisata selam dalam bentuk Peraturan Menteri Pariwisata dan Ekonomi Kreatif. Kesesuaian dengan standar membantu meyakinkan konsumen bahwa produk yang dihasilkan aman, efisien, dan baik untuk lingkungan. Riset ini bertujuan untuk mengetahui tingkat kemampuan dive center dalam memenuhi persyaratan standar usaha wisata selam rekreasi. Terdapat 3 aspek dalam standar usaha wisata selam yang harus dipenuhi oleh pelaku usaha. Aspek pelayanan yang meliputi penyampaian informasi pelayanan merupakan hal utama yang harus dipenuhi oleh pelaku usaha disamping faktor keselamatan dan penanganan kesehatan konsumen. Sedangkan pada aspek produk, hal utama yang perlu dipenuhi adalah peryaratan kompetensi untuk pemandu dan instruktur selam, kepemilikan peralatan permukaan sebagai pendukung keselamatan, kepemilikan peralatan dan paket penyelaman. Aspek pengelolaan termasuk bentuk organisasi, akses layanan kesehatan, sumber daya manusia, dan sarana prasarana juga menjadi persyaratan yang harus dipenuhi. Riset ini juga menghasilkan konsep ekowisata yang mencakup 14 indikator pengelolaan konservasi, 9 indikator manfaat ekonomi, 6 indikator untuk memaksimalkan manfaat bagi masyarakat, pengunjung dan budaya serta meminimalkan dampak negatif, serta 12 indikator untuk manfaat bagi lingkungan dan meminimalkan dampak negatif konservasi. Kesimpulan dari riset ini menunjukkan sebanyak 108 responden pelaku usaha wisata selam (dive center) telah mampu memenuhi persyaratan yang terdapat dalam standar yang telah ditetapkan pemerintah, dan berharap untuk dapat mencapai tujuan keberlangsungan pengelolaan aset wisata dengan dukungan dari pemerintah, masyarakat lokal dan wisatawan.
\end{abstract}

Kata kunci: standar, wisata selam, keberlangsungan, aset wisata.

\section{Abstract}

The minimum requirement organization of recreational activities and best practices certification recreational diving tourism business stipulated in the standard diving tourism business in the form of Regulation of the Minister of Tourism and Economy Creative. Conformity with standards helps convince consumers that the products they produce are safe, efficient, and good for the environment. The purpose of this study is to determine the level of ability and expectation of dive center in applying the standard of diving tourism business. There are 3 aspects in the standard diving business that must be fulfilled by business actors. In the service aspect, it was found that the delivery of service information including preliminary information, information during the provision of services and insurance information, is the main thing that must be fulfilled by the business actor. The next factor is the security and handling of consumer health. In product aspect, guidance competence and diving instructor's requirement is the main thing to be considered by business actor. The next factor is the ownership of surface equipment as a safety support. The last product aspect is proprietary equipment and diving packages. Requirements in the management aspect are organizational forms, access to health services, human resources, and infrastructure facilities. This research also produces an analysis of environmental factors in the management of tourist destinations. Ecotourism concepts include conservation, participation, economics, education, and tourism so that this research produces performance indicators for ecotourism tourism, 14 indicators for conservation management, 9 indicators of economic benefits, 6 indicators to maximize benefits for the community, visitors and culture. as well as minimizing negative impacts, as well as 12 indicators for environmental benefits and minimizing negative impacts. The conclusion of this research indicates that 108 respondents of dive center business have been able to fulfill the requirement in the standard set by the government, and hoped to achieve the goal of sustainable tourism asset management with support from the government, local people and tourists.

Keyword: standard, diving, sustainability, tourism assets. 


\section{PENDAHULUAN}

\subsection{Latar Belakang}

Kepariwisataan merupakan bagian integral dari pembangunan nasional yang dilakukan secara sistematis, terencana, terpadu, berkelanjutan, dan bertanggungjawab dengan tetap memberikan perlindungan terhadap nilai-nilai agama, budaya yang hidup dalam masyarakat, kelestarian dan mutu lingkungan hidup, serta kepentingan nasional (Undang-Undang Nomor 10 Tahun 2009). Pada tahun 2015, penyambutan wisatawan di wilayah Asia Pasifik mencapai 279 juta wisatawan internasional, angka ini tumbuh sebesar $6 \%$ dibandingkan tahun sebelumnya. Untuk wilayah Asia Tenggara, Thailand bangkit dengan kuat sebesar $20 \%$ pada tahun 2015 dengan menyambut 5 juta lebih wisatawan internasional. $\mathrm{Di}$ Thailand, pariwisata merupakan industri yang penting dalam menyediakan lapangan pekerjaan dan mendatangkan devisa bagi Negara (Choovanichchannon, 2015). Myanmar juga mengalami lonjakan sebesar 52\%, Laos sebesar $12 \%$, Filipina sebesar $11 \%$ dan Indonesia juga menikmati dua digit pertumbuhan sebesar $10 \%$. (UNWTO, 2016).

Di dalam Undang-Undang Nomor 10 Tahun 2009 tentang kepariwisataan, hak wisatawan diatur dalam pasal 20b, hak tersebut salah satunya adalah pelayanan kepariwisataaan yang sesuai dengan standar, Untuk mewujudkan hal tersebut, maka para pelaku usaha wisata memiliki kewajiban pengusaha yang diatur dalam pasal $26 n$, yaitu pengusaha pariwisata menerapkan standar usaha dan kompetensi sesuai dengan peraturan perundangan yang berlaku. Dalam undangundang tersebut juga disebutkan pada pasal 54 bahwa produk, pelayanan, dan pengelolaan usaha pariwisata memiliki standar usaha yang disetifikasi oleh lembaga sertifikasi usaha.

Wisata bahari yang meliputi wisata selam, wisata perahu layar, wisata memancing, wisata selancar, dermaga bahari memiliki resiko menyangkut keselamatan, dan keamanan wisatawan merupakan jenis wisata alam yang bersama-sama dengan ekowisata dan wisata petualangan merupakan tujuan dari 35\% dari wisatawan yang datang ke Indonesia (Kementerian Pariwisata, 2014). Dalam mengembangkan wisata bahari di Indonesia, beberapa kegiatan dilakukan, salah satunya adalah menyusun standar dan sertifikasi usaha wisata bahari (Priyono, 2014).

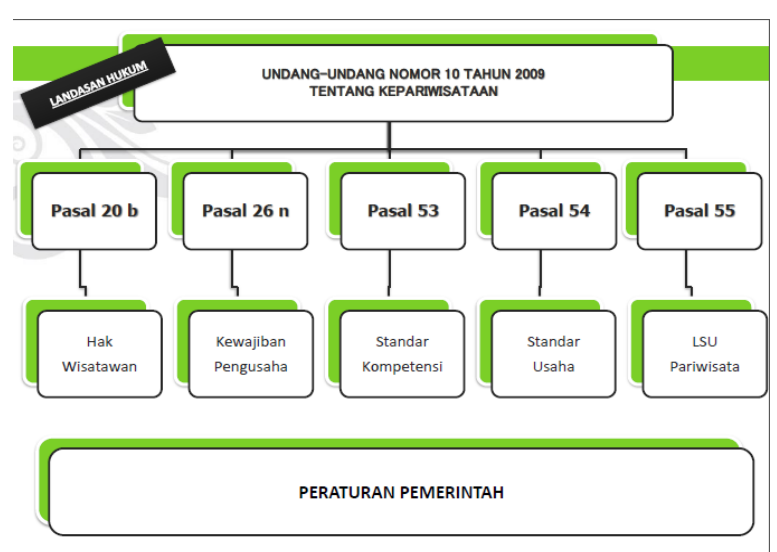

Gambar 1 Undang-Undang Nomor 10 Tahun 2009 Tentang Kepariwisataan.

Karena meningkatnya popularitas scuba diving, pusat kesehatan primer harus terbiasa dengan cedera menyelam yang umum terjadi, antara lain serangan yang terjadi pada paru berpotensi mengancam nyawa, memerlukan perawatan hiperbarik. Penyakit dekompresi adalah hasil pembentukan gelembung di jaringan tubuh. Gejala penyakit dekompresi berkisar dari nyeri sendi hingga masalah neurologis atau paru. (Clenney \& Lassen, 1996).

Di Srilanka dilaporkan, bahwa pada Desember 2017 wisatawan meninggal karena serangan jantung saat melakukan diving. Selain itu, teridentifikasi juga sebanyak 140 wisatawan snorkeling meninggal yang disebabkan oleh jantung atau yang dicurigai penyebab jantung (60), kematian akibat tenggelam di permukaan (sebagian besar pada snorkellers yang tidak berpengalaman) (33), kematian karena tenggelam setelah menyelam yang lama (terutama pada penyelam yang berpengalaman) (19), dan kematian akibat trauma (10) (Lippmann \& Pearn, 2012).

Di Indonesia, media menyebutkan dari tahun ke tahun jumlah kecelakaan selam bervariasi. Korban dapat saja wisatawan penyelam asing maupun wisatawan lokal dimana sepanjang tahun 2015 terdapat sedikitnya 8 korban kecelakaan yang diakibatkan beberapa hal antara lain kepanikan dan hilang (Siaran Pers, 2016).

Masih adanya laporan kecelakaan pada sektor wisata selam, maka sudah menjadi kewajiban para industri wisata selam untuk memenuhi standar kompetensi dan standar usaha wisata selam yang dimilikinya. Kebutuhan para pelaku usaha terhadap standar serta kemampuan mereka dalam menerapkan standar yang telah ada perlu dianalisa, selain itu keinginan dari pelanggan (penyelam) juga perlu digali untuk dapat meningkatkan kualitas dari usaha wisata selam. 
Keberadaan peraturan yang dikeluarkan oleh pemerintah berupa standar usaha wisata selam sudah seharusnya dapat diimplementasikan oleh dive center sebagai salah satu persyaratan utama yang harus dipenuhi. Kebutuhan dan kemampuan pelaku usaha digunakan sebagai respon terhadap pemberlakuan perysaratan dalam standar usaha wisata selam yang telah ditetapkan.

Adanya dugaan bahwa di lapangan masih ditemukan pelaku usaha yang belum mematuhi persyaratan yang diberlakukan sehingga menjadikan persaingan tidak sehat dan mengancam keselamatan wisatawan yang menggunakan jasa penyediaan wisata selam rekreasi, menjadikan penelitian ini penting untuk dilakukan.

Tujuan dari penelitian ini adalah menganalisa kemampuan pelaku usaha dalam pemenuhan persyaratan standar usaha wisata selam yang ditetapkan oleh pemerintah. Penelitian dilakukan pada pelaku usaha wisata selam di wilayah Yogyakarta, Jakarta, Bali, Laboan Bajo, Bogor, Depok, Bekasi.

\section{TINJAUAN PUSTAKA}

\subsection{Wisata Selam}

Wisata selam merupakan bagian dari wisata tirta karena berhubungan langsung dengan air atau dilakukan di perairan pantai, danau, dan sebagainya (Kementerian Pariwisata dan Ekonomi Kreatif, 2014). Meningkatnya minat terhadap wisata selam rekreasi mendorong berkembangnya industri penyelaman di Indonesia, sejalan dengan hal tersebut, maka industri penyelaman harus meningkatkan mutu pelayanan wisata dengan memperhatikan aspek perlindungan bagi keselamatan dan keamanan wisatawan selama rekreasi (Permen No 7 Tahun 2016). Usaha Wisata Selam adalah usaha penyediaan berbagai sarana untuk melakukan penyelaman di bawah atau di permukaan dengan menggunakan peralatan khusus, termasuk penyediaan jasa pemanduan dan perlengkapan keselamatan, untuk tujuan rekreasi.

Scuba diving merupakan salah satu kegiatan wisata. Scuba merupakan singkatan dari Self-Contained Underwater Breathing Apparatus atau Perangkat Bernapas Bawah Air yang Berdiri Sendiri, ditemukan pada tahun 1943 oleh Jacques Yves Cousteau dan Emile Gagnan. Dampak ekonomi secara keseluruhan pariwisata scuba belum dihitung, tapi tidak diragukan lagi sangat besar; misalnya, diperkirakan menyumbang \$AUD 1,7 miliar dalam pengeluaran pariwisata di Great Barrier Reef di
Australia pada tahun 1994 (Musa \& Dimmock, 2012). Scuba diving menghasilkan pengalaman dan mobilisasi emosi bagi para penggemarnya (Straughan, 2012).

Dalam wisata scuba, perhatian khusus diperuntukkan untuk dampak negatif pada terumbu, polusi dari motor boat (Straughan, 2012). Dalam merespon popularitas scuba diving, pertimbangan yang lebih besar diperuntukan pada dampak yang diberikan pada ekosistem laut dan isu yang berhubungan dengan manajemen penyelaman (Hawkins \& Roberts, 1992; Davis \& Tisdell, 1996), masalah fisiologis yang berkaitan dengan menyelam, (Newton 2001; Tetzlaff, 2002), dan pendidikan penyelam (Barker \& Roberts, 2004). Sementara itu, pariwisata scuba diving kemungkinan akan terus tumbuh di seluruh dunia. (Straughan, 2012).

\subsection{Peralatan dasar selam scuba}

Menyelam adalah kegiatan yang dilakukan di bawah permukaan air laut dengan atau tanpa menggunakan peralatan selam, dengan untuk mencapai tujuan tertentu. Peralatan scuba yang diatur dalam Lampiran Peraturan Menteri Nomor 15 Tahun 2014 antara lain: masker selam (diving mask), sepatu katak (fins), pipa udara (snorkel), pakaian selam (wetsuit); sistem pemberat (weight system); regulator (1st stage and 2nd stage); tabung scuba (scuba tank); dan rompi pengatur daya apung (buoyancy control device). Penjelasan masing - masing peralatan berdasarkan USN Diving Manual 6 sebagai berikut:

\section{a. Masker selam (diving mask)}

Penglihatan di dalam air sangat buruk, maka diperlukan peralatan yang memberikan manfaat membuat kantong hawa pada mata serta hidung sehingga penyelam mampu melihat di kedalaman air, serta membantu untuk mencegah iritasi. Masker selam harus kedap air dan sesuai dengan bentuk muka penyelam.

\section{b. Sepatu katak (fins)}

Dalam melakukan penyelaman, kemampuan kaki harus dibantu peralatan untuk memudahkan pergerakan dengan cepat dan nyaman. Sepatu katak (fins) digunakan untuk menaikkan daya kayuh, sehingga kecepatan berenang menjadi lebih besar. Terdapat 3 (tiga) jenis fins yang dikenal, adalah foot pocket, open heel, dan adjustable open heel.

\section{c. Pipa udara (snorkel)}

Pipa udara (snorkel) digunakan untuk bernafas di permukaan air sewaktu penyelam skin diving beristirahat di permukaan. 


\section{d. Pakaian selam (wetsuit)}

Penggunaan pakaiam selam bertujuan untuk memperlambat kehilangan panas tubuh dan melindungi tubuh dari goresan karang maupun sengatan kehidupan laut. Pemilihan pakaian selam disesuaikan dengan ukuran tubuh dan kebutuhan penyelaman.

e. Sistem pemberat (weight system)

Tubuh manusia akan mendapat daya apung ke atas di dalam air. Peralatan pemberat dibutuhkan sehingga penyelam dengan mudah masuk ke laut. Pemberat yang paling banyak digunakan berbentuk weight belt, alat ini dengan mudah dipasang dan mudah dilepas dalam keadaan darurat.

\section{f. Regulator (1st stage and 2nd stage)}

Regulator adalah suatu alat yang sederhana untuk mengubah udara bertekanan tinggi dari sebuah tabung scuba menjadi udara bertekanan rendah sesuai dengan kebutuhan penyelam dan hanya memberikan udara yang diperlukan sesuai dengan tekanan sekelilingnya.

g. Tabung scuba (scuba tank)

Tabung scuba dirancang secara khusus untuk menampung udara bertekanan tinggi. Udara yang diisikan dalam tabung adalah udara biasa yang disaring bukan oksigen murni, yaitu udaha yang biasa dihirup setiap hari. Pengisian dan perawatan tabung dilakukan oleh petugas yang telah terlatih.

h. Rompi pengatur daya apung (buoyancy control device).

Rompi apung dipergunakan untuk keadaan darurat. Di dalam kegiatan penyelaman, rompi ini dipergunakan untuk terapung di permukaan air sambal berenang, istirahat di permukaan air, penyelamatan diri sendiri dan orang lain, netralisasi keterapungan dalam setiap kedalaman.

Saat ini penyusunan standar pariwisata yang berhubungan dengan sistem manajemennya telah menjadi program dari Badan Standardisasi Nasional, namun untuk standar produk yang mendukung kegiatan wisata juga perlu dilakukan kajian kebutuhannya.

\section{METODE PENELITIAN}

Penelitian ini terbagi dalam beberapa tahapan, tahap pertama dilakukan studi pendahuluan yang meliputi studi pustaka terkait teori yang mendukung terkait penelitian dan diskusi dengan pakar mengenai standar wisata selam. Output dari tahap ini adalah gap atau peluang penelitian berupa program pengembangan standar usaha pariwisata serta untuk menentukan persyaratan standar mengenai usaha wisata selam rekreasi.

Berdasarkan parameter standar yang telah diperoleh dari studi pendahuluan maka dilakukan pengumpulan data melalui kuesioner terhadap responden penelitian yaitu pengelola usaha wisata selam rekreasi di Indonesia dengan asumsi semua usaha wisata selam ini bersifat homogen. Asumsi ini ditetapkan karena seluruh usaha wisata selam di Indonesia belum ada yang melakukan sertifikasi berdasarkan persyaratan yang ada di dalam standar usaha wisata selam.

$\begin{array}{ccc}\text { Tahap } & \text { berikutnya, dilakukan } \\ \text { pengelompokkan } & \text { berdasarkan } & \text { tingkat }\end{array}$ kepentingan dari parameter persyaratan standar mengenai usaha wisata selam rekreasi yang telah diperoleh sehingga akan didapatkan batasan penilaian untuk setiap kategori dari persyaratan standar, yaitu aspek produk, pelayanan dan pengelolaan. Berdasarkan hal tersebut dilakukan analisa factor dengan jumlah sampel 108 responden karena merupakan jumlah ideal sampel untuk melakukan analisa faktor (Daely dkk, 2013).

Tahapan yang terakhir adalah memperoleh kembali informasi dari pakar terkait usaha wisata selam rekreasi mengenai Global Sustainable Tourism Council Criteria serta konservasi alamnya sehingga dari seluruh data yang diperoleh dapat diperoleh kesimpulan mengenai bagaimana pemenuhan persyaratan standar wisata selam rekreasi di Indonesia dengan didukung program yang sustainable terhadap lingkungan.

\section{HASIL DAN PEMBAHASAN}

\subsection{Pemenuhan Standar Usaha Wisata Selam Rekreasi}

Berdasarkan Peraturan Menteri Nomor 15 Tahun 2014, usaha pariwisata adalah usaha yang menyediakan barang dan/atau jasa bagi pemenuhan kebutuhan wisatawan dan penyelenggaraan pariwisata. Usaha wisata selam adalah usaha penyediaan berbagai sarana untuk melakukan penyelaman di bawah atau di permukaan air dengan menggunakan peralatan khusus, termasuk penyediaan jasa pemanduan dan perlengkapan keselamatan, untuk tujuan rekreasi. Di dalam peraturan tersebut diatur mengenai penyelenggaraan usaha wisata selam; sertifikat dan sertifikasi usaha wisata selam; pembinaan dan pengawasan; dan sangsi administratif. 


\subsubsection{Aspek Produk}

Pada proses pengelompokkan berdasarkan tingkat kepentingan menggunakan analisa faktor maka diperoleh tiga kriteria yang menjadi representasi dari tanggapan dari responden yaitu kriteria utama (persyaratan yang sangat penting) yaitu mutlak harus ada dalam persyaratan tersebut, kemudian kriteria kedua (persyaratan yang penting) dan kriteria ketiga (persyaratan yang cukup penting).

Tabel 1 memperlihatkan bahwa kriteria utama dalam persyaratan wisata selam adalah kompetensi atau lisensi pemandu dan instruktur selam dari agen pelatihan nasional/internasional yang bereputasi baik serta pengetahuan dan rekam jejak tentang lokasi penyelaman dan kemampuan penanganan keselamatan wisatawan, termasuk penanganan keadaan darurat di bawah air. Hal ini dikarenakan dalam wisata selam, aset utama yang dapat ditawarkan pada wisatawan adalah keindahan di bawah laut, sehingga peran dari instruktur selam sangat besar.

Tabel 1 Penilaian responden terhadap persyaratan dalam aspek produk.

\section{Kode Produsen}

Grup 1: Kriteria utama

Q11 Pemandu selam memiliki kompetensi/lisensi dari agen pelatihan selam nasional/internasional Q11 yang memiliki reputasi baik

Q12 Pemandu selam memiliki kompetensi/lisensi sebagai instruktur selam dari agen (agency) pengenalan penyelaman scuba

Pemandu selam memiliki pengetahuan dan rekam jejak tentang lokasi penyelaman dan

Q13 kemampuan penanganan keselamatan wisatawan, termasuk penanganan keadaan darurat di bawah air

Grup 2: Kriteria kedua

Q17 Memiliki alat komunikasi

Q15 Memiliki pelampung penanda permukaan (SMB)

Q16 Memiliki pelampung dengan tanda dan bendera selam

Q18 Memiliki kapal untuk menyelam sesuai dengan lokasi penyelaman, dan memiliki sarana pelampung

Memiliki perlengkapan P3K dan oksigen sesuai standar peralatan keselamatan penyelaman

Q14 yang direkomendasikan oleh agensi selam dan/atau ketentuan peraturan perundangundangan

Grup 3: Kriteria ketiga

\begin{tabular}{ll}
\hline Q08 & Memiliki peralatan : Regulator \\
\hline Q10 & Memiliki peralatan : Rompi pengatur daya apung \\
\hline Q03 & Memiliki peralatan : Masker selam \\
\hline Q04 & Memiliki peralatan : Sepatu katak \\
\hline Q09 & Memiliki peralatan : Tabung scuba \\
\hline Q06 & Memiliki peralatan : Pakaian selam \\
\hline Q07 & Memiliki peralatan : Sistem pemberat \\
\hline Q05 & Memiliki peralatan : Pipa udara \\
\hline Q02 & $\begin{array}{l}\text { Layanan yang diberikan oleh dive center meliputi: paket wisata, pendidikan dan pelatihan, dan } \\
\text { penyewaan alat selam }\end{array}$ \\
\hline
\end{tabular}

Kelompok kriteria kedua adalah kepemilikan peralatan yang digunakan untuk berkomunikasi pada saat melakukan kegiatan wisata selam, misalnya alat komunikasi penanda permukaan, pelampung dengan tanda dan bendera selam, kapal untuk menyelam lengkap dengan sarana pendukungnya. Peralatanperalatan perlu dimiliki oleh pelaku usaha wisata selam untuk dapat memberikan tanda kepada kapal-kapal lain bahwa pada saat tersebut ada kegiatan penyelaman di bawah laut disekitar tanda tersebut. Selain itu, perlengkapan yang juga penting dimiliki oleh pelaku usaha adalah perlengkapan P3K dan oksigen sesuai standar peralatan keselamatan penyelaman yang direkomendasikan oleh agensi selam dan/atau ketentuan peraturan perundang-undangan, mengingat kegiatan menyelam ini merupakan kegiatan yang beresiko tinggi.

Kelompok kriteria ketiga merupakan kriteria penting namun tidak harus dimiliki oleh para pelaku usaha, namun harus dapat 
disediakan pada saat ada kegiatan wisata selam. Penyediaan tersebut dapat dengan cara memiliki sendiri atau menyewa ke penyedia peralatan wisata selam. Pada kriteria ini, para pelaku usaha dapat memberdayakan para pelaku usaha penyewaan peralatan yang biasanya berada di daerah, sehingga konsep ekowisata untuk memberikan manfaat pada daerah sekitar dapat terwujud. Analisa ini selaras dengan Ismayanti (2010) yang menyebutkan bahwa dampak positif dari pertumbuhan usaha wisata selam adalah:

○ meningkatnya struktur ekonomi

- membuka peluang investasi

- mendorong aktivitas wirausaha (entreprenurships).

\subsubsection{Aspek pelayanan}

Pada aspek pelayanan, kriteria dikelompokkan menjadi 3 kelompok menurut tingkat kepentingannya untuk diadopsi menjadi standar ekowisata selam rekreasi. Tabel 2 menunjukkan tanggapan responden terhadap persyaratan dalam aspek pelayanan. Kriteria utama dari aspek pelayanan adalah kepemilikan prosedur dalam pelaksanaan kegiatan wisata selam, seperti prosedur supervisi penyelaman, penggunaan kapal, keselamatan atau pertolongan pertama pada kecelakaan, pelaksanaan kegiatan, menangani keluhan wisata. Kepemilikan prosedur pelayanan administrasi yang terkelompok pada kriteria kedua adalah prosedur metode pembayaran, pemberian informasi paket wisata melalui media, serta pelayanan dan penjemputan serta pengantaran wisatawan.

Tabel 2 Penilaian responden terhadap persyaratan dalam aspek pelayanan.

\begin{tabular}{ll}
\hline Kode & Produsen \\
\hline Grup 1: & Kriteria utama \\
\hline Q25 & Memiliki SOP dalam supervisi penyelaman \\
\hline Q26 & Memiliki SOP dalam penggunaan kapal \\
\hline Q27 & Memiliki SOP keselamatan atau pertolongan pertama pada kecelakaan \\
\hline Q24 & Memiliki SOP dalam pelaksanaan kegiatan \\
\hline Q29 & Memiliki SOP dalam menangani keluhan wisatawan \\
\hline Grup 2: & riteria kedua \\
\hline Q22 & Memiliki SOP untuk pembayaran tunai dan/atau non tunai \\
\hline Q20 & $\begin{array}{l}\text { Memiliki SOP dalam penerimaan dan pemberian informasi melalui telepon, } \\
\text { faksimili, dan email mengenai: paket kegiatan, jadwal, produk, dan harga }\end{array}$ \\
\hline Q23 & Memberikan layanan dan SOP penjemputan dan pengantaran wisatawan \\
\hline Grup 3: Kriteria ketiga \\
\hline Q28 & $\begin{array}{l}\text { Memiliki penjagaan keamanan oleh satuan pengamanan di lokasi kantor, yang } \\
\text { memiliki kartu tanda anggota (KTA) satuan pengamanan yang dikeluarkan oleh } \\
\text { kepolisian RI }\end{array}$ \\
\hline Q30 & Memberikan pelayanan asuransi untuk pegawai dan wisatawan \\
\hline
\end{tabular}

Kriteria kedua dalam aspek pelayanan ini mencakup kepemilikan prosedur untuk cara pembayaran paket wisata, pemberian informasi paket wisata yang diberikan kepada calon wisatawan, serta kepemilikan prosedur penjemputan dan pengantaran wisatawan. Hal ini menjadi penting karena para wisatawan menginginkan informasi yang jelas dan cepat serta dapat dipercaya.

Kriteria ketiga menurut tingkat kepentingannya pada aspek pelayanan adalah penjagaan keamanan dan pelayanan pemberian asuransi. Tenaga penjagaan keamanan tidak harus dimiliki oleh pelaku usaha wisata selam, tenaga tersebut dapat disewa. Selain itu, pelayanan asuransi juga bisa disediakan oleh perusahaan asuransi yang menjalin kerjasama dengan pelaku usaha wisata. Pengelola tempat 38 wisata yang memiliki resiko tinggi menggunakan jasa pihak ketiga dalam hal ini perusahaan asuransi untuk menanggung risiko terhadap wisatawan apabila terjadi hal-hal yang tidak diinginkan.

\subsubsection{Aspek Pengelolaan}

Aspek pengelolaan wisata selam merupakan kriteria-kriteria yang diperlukan dalam melakukan kegiatannya. Kriteria program peningkatan kompetensi untuk pemandu dan staf operasional kembali menjadi kriteria utama untuk aspek ini. Pelaku usaha wisata selam juga harus memiliki dan melaksanakan program pemeriksaan kesehatan bagi para pemandunya. Selain itu, pada saat menawarkan paket wisata selam, para pelaku usaha juga harus dapat menunjukkan informasi lengkap mengenai dokter, klinik atau 
rumah sakit terdekat; peralatan komunikasi khusus untuk koordinasi dan keadaan darurat; program pengawasan kegiatan penyelaman yang ramah lingkungan dan mengikuti kaidah konservasi dan pengamatan biota laut yang terdokumentasi.

Kriteria kedua menurut tingkat kepentingan dari para pelaku usaha adalah kriteria yang mencakup penyediaan sarana dan prasarana di sebuah kantor dan tempat penyelenggaraan wisata selam. Hal ini dikarenakan didalam paket wisata terdapat kegiatan training untuk melihat kemampuan calon wisatawan selam. Training tersebut dilakukan secara teori dan praktek, sehingga fasilitas-fasilitas dalam kantor diperlukan untuk menunjang kegiatan tersebut. Fasilitas-fasilitas yang masuk ke dalam kriteria kedua ini tidak harus ada di kantor pelaku usaha wisata, namun mereka dapat menyewa tempat lain yang digunakan untuk melaksanakan kegiatannya. Fasilitas yang dapat disediakan antara lain penyediaan toilet, kamar bilas dan kamar ganti yang terpisah antara pria dan wanita, dan beberapa fasilitas yang ditampilkan dalam Tabel 3. Pada umumnya, tempat ini menjadi satu dengan kolam renang yang sengaja disewa untuk melaksanakan kegiatan training praktek menyelam.

Kriteria yang masuk ke dalam kelompok ketiga dalam aspek pengelolaan meliputi dokumen-dokumen yang harus dimiliki oleh para pelaku usaha untuk menunjang keberlangsungan usahanya. Dokumen tersebut harus terjaga dan terpelihara keterbaruannya, disesuaiakan dengan kegiatan usaha wisata selam yang dilakukan. Selain itu, evaluasi kerja juga sebaiknya dilakukan untuk menjaga kualitas pelayanan yang diberikan.

Tabel 3 Penilaian responden terhadap persyaratan dalam aspek pengelolaan.

\begin{tabular}{|c|c|}
\hline Kode & Produsen \\
\hline \multicolumn{2}{|c|}{ Grup 1: Kriteria utama } \\
\hline Q38P & Memiliki staf operasional yang memahami usaha wisata selam \\
\hline Q37P & $\begin{array}{l}\text { Melaksanakan program pengawasan kegiatan penyelaman yang ramah lingkungan dan } \\
\text { mengikuti kaidah konservasi dan pengamatan biota laut yang terdokumentasi }\end{array}$ \\
\hline Q48 & Memiliki peralatan komunikasi khusus untuk koordinasi dan keadaan darurat \\
\hline Q39P & $\begin{array}{l}\text { Melaksanakan program pemeriksaan kesehatan bagi pemandu selam paling sedikit } \\
\text { sekali dalam } 1 \text { tahun }\end{array}$ \\
\hline Q40 & Memiliki program pelatihan peningkatan kompetensi \\
\hline Q35P & Memiliki informasi lengkap mengenai dokter, klinik atau rumah sakit terdekat \\
\hline Q38P & Memiliki staf operasional yang memahami usaha wisata selam \\
\hline \multicolumn{2}{|c|}{ Grup 2: Kriteria kedua } \\
\hline Q53 & $\begin{array}{l}\text { Toilet pria dan wanita yang terpisah dengan sirkulasi pencahayaan udara yang sesuai } \\
\text { dengan ketentuan peraturan perundang-undangan }\end{array}$ \\
\hline Q52 & $\begin{array}{l}\text { Menyediakan kamar bilas dan kamar ganti pria dan wanita yang terpisah dengan } \\
\text { sirkulasi dan pencahayaan udara yang sesuai dengan peraturan perundang-undangan }\end{array}$ \\
\hline Q55 & Memiliki instalasi air bersih sesuai dengan ketentuan peraturan perundang-undangan \\
\hline Q54 & Memiliki instalasi listrik sesuai dengan ketentuan peraturan perundang-undangan \\
\hline Q49 & Memiliki ruang medis yang dilengkapi: oksigen, tempat tidur, dan peralatan P3K \\
\hline Q50 & $\begin{array}{l}\text { Memiliki ruang atau area perbaikan, penyimpanan dan pamajangan peralatan } \\
\text { penyelaman }\end{array}$ \\
\hline Q45 & Terdapat tempat penyimpanan barang berharga yang aman \\
\hline Q47 & Memiliki peralatan komunikasi yang terdiri dari telepon, faksimili dan fasilitas internet \\
\hline Q44 & Terdapat tempat penitipan barang yang aman \\
\hline Q56 & Menyediakan ruang atau area ibadah dengan kelengkapannya \\
\hline Q51 & $\begin{array}{l}\text { Memilki alat pemadam api ringan (APAR) sesuai dengan ketentuan peraturan } \\
\text { perundang-undangan }\end{array}$ \\
\hline \multicolumn{2}{|c|}{ Grup 3: Kriteria ketiga } \\
\hline Q33P & Memiliki rencana usaha yang lengkap terukur, dan terdokumentasi dengan baik \\
\hline Q32P & Dokumen prosedur operasional standar dan/atau petunjuk pelaksanaan kerja \\
\hline Q41P & Memiliki perencanaan dan pengembangan karier \\
\hline Q31P & $\begin{array}{l}\text { Adanya dokumen profil perusahaan yang terdiri atas: visi dan misi, struktur organisasi } \\
\text { yang lengkap dan terdokumentasi, serta uraian tugas dan fungsi yang lengkap untuk } \\
\text { setiap jabatan dan terdokumentasi }\end{array}$ \\
\hline
\end{tabular}




\begin{tabular}{ll}
\hline Kode & Produsen \\
\hline Q36P & Melaksanakan evaluasi kinerja manajemen yang terdokumentasi \\
\hline Q34P & Memiliki pelaksanaan program K3 yang terdokumentasi dengan baik \\
\hline Q43P & Terdapat meja dan kursi pada area kantor depan (front office) \\
\hline Q42P & $\begin{array}{l}\text { Ruang kantor yang dilengkapi peralatan dan perlengkapan dengan sistem pencahayaan } \\
\text { dan sirkulasi udara sesuai dengan ketentuan peraturan perundangan }\end{array}$ \\
\hline Q46 & $\begin{array}{l}\text { Papan nama yang dibuat dari bahan aman dan kuat dengan tulisan yang terbaca dan } \\
\text { terlihat jelas serta dipasang sesuai dengan ketentuan peraturan perundang-undangan }\end{array}$ \\
\hline
\end{tabular}

\subsection{Global Sustainable Tourism Council Criteria (GSTC)}

Industri pariwisata merupakan industri yang berdampak global terhadap ekonomi, sosial, dan lingkungan. Pariwisata berkelanjutan bertujuan untuk meminimalkan dampak negatif serta meminimalkan kerugian, sekaligus memaksimalkan manfaat ekonomi. Menurut World Tourism Organization (UN-WTO), pariwisata berkelanjutan adalah pariwisata yang dianggap mengarah pada pengelolaan semua sumber daya sedemikian rupa sehingga ekonomi, social dan kebutuhan estetika dapat dipenuhi dengan menjaga integritas budaya, proses ekologis yang penting, keragaman biologis, dan system pendukung kehidupan. (Oehms \& Vitriani, 2016).

GSTC adalah organisasi non-profit independen terdaftar di Amerika Serikat, yang menetapkan dan mengelola standar internasional untuk meningkatkan pengetahuan dan praktek tentang pariwisata yang berkelanjutan. Global Sustainable Tourism Council (GSTC) menetapkan dan mengelola standar keberlanjutan global dengan tujuan untuk meningkatkan pengetahuan dan praktik pariwisata yang berkelanjutan di kalangan pemangku kepentingan publik dan swasta. GSTC bersifat independen dan netral, melayani peran penting dalam mengelola standar dasar global untuk keberlanjutan dalam perjalanan dan pariwisata.

Global Sustainable Tourism
(GSTC) diciptakan dalam upaya

mendapatkan pemahaman umum tentang pariwisata berkelanjutan. Kriteria GSTC merupakan upaya minimum yang perlu dicapai oleh setiap organisasi manajemen pariwisata ketika mempertimbangkan keberlanjutan dalam praktik mereka. Untuk memenuhi definisi pariwisata berkelanjutan, destinasi harus mengambil pendekatan interdisipliner, holistik dan integratif yang meliputi empat tujuan utama:

a. Mendemonstrasikan pengelolaan destinasi yang berkelanjutan,

b. Memaksimalkan keuntungan ekonomi untuk masyarakat lokal dan meminimalkan dampak negatif,

c. Memaksimalkan keuntungan untuk masyarakat, pengunjung dan budaya serta meminimalkan dampak negatif,

d. memaksimalkan manfaat untuk lingkungan dan meminimalkan dampak negatif. Kriteria GSTC dirancang untuk dapat digunakan oleh semua jenis dan skala destinasi.

Kriteria GSTC untuk destinasi disusun sebagai awal suatu proses untuk membuat keberalanjutan menjadi praktek standar di semua bentuk pariwisata, termasuk wisata selam. Karena destinasi terdiri atas banyak perusahaan, organisasi dan individu yang berbeda, penerapan kriteria ini harus mencakup pertimbangan yang matang mengenai efek kumulatif dari kegiatan-kegiatannya. Kriteria dari GSTC untuk wisata selam yang dapat dijadikan indikator disajikan dalam Tabel 4 berikut:

Tabel 4 Kriteria GSTC untuk destinasi wisata.

\begin{tabular}{ll}
\hline Bagian & Kriteria \\
\hline Pengelolaan konservasi: & 1. Strategi destinasi berkelanjutan \\
Mendemonstrasikan pengelolaan & 2. Organisasi manajemen destinasi \\
destinasi yang berkelanjutan & 3. Monitoring \\
& 4. Pengelolaan Pariwisata Musiman \\
& 5. Adaptasi terhadap Perubahan Iklim \\
& 6. Inventarisasi Aset dan Atraksi Pariwisata \\
& 7. Pengaturan Perencanaan \\
& 8. Akses untuk Semua \\
& 9. Akuisisi Properti \\
\hline
\end{tabular}




\begin{tabular}{ll}
\hline Bagian & Kriteria \\
\hline & 10. Kepuasan Pengunjung \\
& 11. Standar Keberlanjutan \\
& 12. Keselamatan dan Keamanan \\
& 13. Manajemen Krisis dan Kedaruratan \\
& 14. Promosi \\
\hline Manfaat ekonomi: & 1. Pemantauan Ekonomi \\
Memaksimalkan manfaat ekonomi & 2. Peluang Kerja untuk Masyarakat Lokal \\
untuk masyarakat lokal dan & 3. Partisipasi Masyarakat \\
meminimalkan dampak negatif & 4. Opini Masyarakat Lokal \\
& 5. Akses Bagi Masyarakat Lokal \\
& 6. Fungsi Edukasi Sadar Wisata \\
7. Pencegahan eksploitasi \\
8. Dukungan untuk Masyarakat \\
Manfaat bagi masyarakat: & 9. Mendukung pengusaha lokal dan perdagangan yang adil \\
memaksimalkan manfaat bagi & 2. Perlindungan Atraksi Wisata \\
masyarakat, pengunjung dan & 3. Perilaku Pengunjung \\
dampak, serta meminimalkan & 4. Perlindungan Warisan Budaya \\
& 5. Interpretasi Tapak \\
\hline Manfaat bagi lingkungan: & 6. Perlindungan Kekayaan Intelektual \\
Memaksimalkan manfaat bagi & 1. Risiko Lingkungan \\
lingkungan dan meminimalkan & 3. Perlindungan Lingkungan Sensitif \\
dampak & 4. Perlindungan Alam Liar (Flora dan Fauna) \\
negatif & 5. Konservasi Energi \\
& 6. Pengelolaan Air \\
7. Keamanan Air \\
8. Kualitas Air \\
9. Limbah Cair \\
10. Mengurangi Limbah Padat \\
11. Polusi Cahaya dan Suara \\
12. Transportasi Ramah Lingkungan \\
\hline
\end{tabular}

sumber: GSTC, 2013 \& data penelitian (diolah).

Pada wisata selam, salah satu objek yang sering ditawarkan adalah keindahan terumbu karang. Meskipun masih banyak lagi keindahan bawah laut yang bisa dinikmati oleh para peselam.

Tabel 5 Luas terumbu karang Indonesia.

\begin{tabular}{lll}
\hline No & Regional & Luas(Ha) \\
\hline 1 & Bali & 8.837 \\
\hline 2 & Jawa & 67.869 \\
\hline 3 & Kalimantan & 119.304 \\
\hline 4 & Maluku & 439.110 \\
\hline 5 & Nusa Tenggara & 272.123 \\
\hline 6 & Papua & 269.402 \\
\hline 7 & Sulawesi & 862.627 \\
\hline 8 & Sumatera & 478.587 \\
\hline & Total & 2.517 .858 \\
\hline Sumber: Giyanto dkk, 2017
\end{tabular}

Ekosistem terumbu karang terdapat hampir di semua wilayah yang disurvei dalam penelitian ini. Epstein dkk (2001) menyatakan bahwa kegiatan scuba diving, snorkeling dan menginjak-nginjak area terumbu adalah kegiatan yang banyak dilakukan wisatawan di seluruh dunia. Kegiatan tersebut jelas memberikan dampak negarif pada persent tutupan karang hidup, ukuran koloni karang dan pecahnya koloni karang menjadi kecil.

Di Yogyakarta, kondisi terumbu karang di Pantai Sadranan sudah banyak yang rusak, hal ini dikarenakan para penikmat keindahan bawah laut melalui kegiatan snorkling tidak diberikan training terlebih dahulu sebelum melakukan snorkeling. Para penyedia jasa pariwisata kurang peduli terhadap keberlangsungan ekosistem terumbu karang. Hal ini seperti dilaporkan oleh Yuliani (2016), bahwa di kawasan Lhokseudu Aceh sebagai salah satu kawasan yang terdiri dari ekosistem terumbu karang, bahwa perbandingan kondisi terumbu karang pada tahun 2008 dan 2016 berbeda, dimana kondisi tutupan karang menurun pada tahun 2016, karang mati, alga meningkat. Kerusakan ini didominasi oleh rubble. Rusaknya karang di 
wilayah perairan Pulau Sempu hampir sama penyebabnya yaitu adanya faktor tekanan dari manusia yang lebih dominan seperti kegiatan wisata berjalan dan mencari kerang ketika surut terendah, berdiri dan menginjak karang ketika snorkeling atau berenang (Luthfi, 2016).

Kerusakan terumbu karang telah lama ditemukan oleh para peneliti, seperti dilaporkan juga oleh Kunzmann \& Effendi (1994) bahwa keadaan terumbu karang di sepanjang pantai Sumater Barat sudah sangat rusak dan teancam punah. Berdasarkan fakta yang ada, kegiatan untuk merusak terumbu karang tersebut hanya perlu waktu 2 jam, sedangkan upaya karang untuk tumbuh kembali membutuhkan waktu selama 10-15 tahun. Penyebab terjadinya kerusakan terumbu karang oleh manusia salah satunya adalah pengaruh aktivitas komersial dan rekreasi di wilayah tumbuhnya terumbu karang.

Studi yang lainnya mengeksplorasi motivasi penyelam di Azores dalam hubungan dengan variabel demografi dan tingkat spesialisasi, berdasarkan survei terhadap 425 penyelam di lima dari sembilan pulau. Dengan menggunakan analisis komponen cluster dan komponen utama, empat kelompok penyelam dibedakan: penyelam sosializer, hiu dan manta; pencari keragaman hayati dan penyelam penjelajah. Aspek sosial penting bagi generalis dan spesialis dan pentingnya fauna bawah air tidak meningkat dengan spesialisasi. Latar belakang budaya penyelam mempengaruhi motivasinya. Temuan menyoroti pentingnya memahami motivasi penyelam, mengembangkan program kesadaran penyelam pada semua tahap spesialisasi dan juga strategi manajemen terpadu. (Bentz dkk, 2016).

Sebagai uapaya pencegahan dan perbaikan kondisi biota laut, beberapa strategi diusulkan, antara lain dengan penerapan prinsip ekowisata. Usulan ini disampaikan oleh Tinumbia dkk (2016) untuk pembangunan fasilitas terpadu dalam pengelolaan ekosistem terumbu karang di Gili Trawangan diharapkan dapat meningkatkan minat serta kepedulian masyarakatdalam menjaga kelestarian alam melalui programprogram aktivitas yang diselenggarakan. Teknologi untuk melakukan konservasi terumbu karang telah diusulkan dan di tindak lanjuti sejak lama, seperti penelitian yang dilakukan oleh Santoso \& Kardono (2008) yang mengusulkan strategi yang diperlukan dalam pengelolaan terumbu karang yang meliputi pemberdayaan masyarakat pesisir secara langsung, mengurangi laju degradasi dan pengelilaan terumbu karang berdasarkan kerakteristik ekosistem, potensi, pemanfaatan dan status hukumnya. Teknologi yang dikembangkan untuk konservasi terumbu karang meliputi terumbu karang buatan, pencangkokan dan mineral accretion.

Usulan lainnya disampaikan oleh Luthfi (2016) untuk melakukan konservasi terumbu karang di Pulau Sempu dengan menggunakan konsep taman karang. Dalam usulan itu, hal-hal yang perlu dilakukan adalah pengenalan jenisjenis karang, pelatihan metode transplantasi karang, pelatihan pembuatan taman karang, penurunan media, dan transplantasi karang.

\subsection{Pariwisata, keberlanjutan, dan sertifikasi}

Pariwisata yang merupakan bisnis yang luas dan terus meluas di seluruh dunia memberikan dampak positif dan negatif pada sosial, ekonomi dan lingkungannya. Pariwisata yang berkelanjutan bertujuan untuk memberikan dampak negatif yang minimal, meminimalkan kerugian dan mengoptimalkan manfaat ekonomi. Ekowisata merupakan pariwisata lestari yang biasanya dilakukan di daerah alami yang sebagian besar tidak tersentuh, yang cenderung sensitif secara lingkungan dan seringkali sensitif secara sosial (terutama jika kelompok masyarakat adat), sehingga dampak potensinya dapat lebih besar lagi, baik atau buruk. Ekowisata bertujuan untuk memperluas dampak positif, melalui fokus khusus pada konservasi, manfaat bagi populasi tuan rumah, dan pendidikan pengunjung.

Salah satu cara untuk memberi penghargaan kepada bisnis yang benar-benar mematuhi tujuan ini adalah dengan memberi mereka pengakuan luar yang kredibel. Sertifikasi adalah alat untuk melakukannya. Konsep pariwisata yang berkelanjutan dapat diterapkan untuk berbagai tipe pariwisata, baik itu pariwisata massal dan individual dimanapun berada. Program dari United Nations Environment Programme - World Tourist Organization (2005) mendeskripsikan 12 (dua belas) tujuan untuk membuat pariwisata berkelanjutan adalah:

a. Kelangsungan ekonomi: Memastikan kelangsungan dan daya saing destinasi wisata dan perusahaan, sehingga dapat terus makmur dan memberikan keuntungan dalam jangka panjang

b. Kesejahteraan lokal: memaksimalkan kontribusi pariwisata terhadap kemakmuran ekonomi dari destinasinya.

c. Kualitas Pekerja: memperkuat jumlah dan kualitas pekerja lokal yang diciptakan dan didukung oleh pariwisata, termasuk tingkat upah, kondisi pelayanan dan ketersediaan untuk semua orang tanpa diskriminasi menurut jenis kelamin, ras, kecacatan, dll 
d. Kualitas sosial: untuk mencari distribusi manfaat ekonomi dan social yang meluas dan adil dari pariwisata di seluruh masyarakat.

e. Pemenuhan pengujung: untuk memberikan pengalaman yang aman dan memuaskan bagi pengunjung, tersedia bagi semua orang tanpa diskriminasi menurut jenis kelamin, ras, kecacatan

f. Pengendalian lokal: untuk melibatkan dan memberdayakan masyarakat local dalam perencanaan dan pengambilan keputusan tentang pengelolaan dan pengembangan masa depan pariwisata di wilayahnya melalui konsultasi dengan pemangku kepentingan.

g. Kekayaan budaya: Untuk menghormati dan meningkatkan warisan sejarah, budaya otentik, tradisi, dan kekhasan komunitas tuan rumah.

h. Integritas Fisik: Untuk menjaga dan meningkatkan kualitas destinasi, baik perkotaan maupun pedesaan, dan hindari degradasi fisik dan visual lingkungan.

i. Keanekaragaman Hayati: Untuk mendukung konservasi kawasan alami, habitat, dan satwa liar, dan meminimalkan kerusakan pada mereka.

j. Efisiensi Sumber Daya: Untuk meminimalkan penggunaan sumber daya langka dan tidak terbarukan dalam pengembangan dan pengoperasian fasilitas dan layanan pariwisata.

k. Kemurnian Lingkungan: Untuk meminimalkan polusi udara, air, dan tanah dan pembangkitan limbah oleh perusahaan pariwisata dan pengunjung

Ekowisata adalah sektor pariwisata berdasarkan perjalanan alam dan termasuk prinsip keberlanjutan. The International Ecotourism Society (TIES) mendefinisikan ekowisata adalah kegaitan perjalanan ke daerahdaerah alami yang melestarikan lingkungan dan meningkatkan kesejahteraan masyarakat setempat. Masalah utama yang sering ditemui adalah praktek yang disebut greenwashing, yaitu pebisnis yang mengaku sebagai bisnis yang berkelanjutan, namun tidak sesuai dengan standar yang berlaku umum, atau bahkan lebih buruk lagi. Hal tersebut akan kontradiksi dengan pengakuan mereka.

Bagi bisnis yang benar-benar berusaha melakukan yang terbaik untuk mematuhi semua standar ekowisata, cara tersebut menjadi tidak adil dan merusak kredibilitas keseluruhan industri. Salah satu cara untuk menentukan bisnis mana yang benar-benar mempraktikkan ekowisata (atau pariwisata berkelanjutan di segmen pasar lainnya) adalah sertifikasi. The World Tourism Organization (2002) telah mengidentifikasi 60 program sertifikasi ekowisata dan berkelanjutan di seluruh dunia. Beberapa program beroperasi di seluruh dunia, beberapa bersifat regional, dan sebagian besar bersifat nasional atau lokal. Sejumlah studi telah membandingkan program sertifikasi, untuk menentukan bagaimana perbedaannya dan di mana mereka dapat ditingkatkan.

\subsection{Program agency selam untuk konservasi wisata selam}

\subsubsection{Professional Association of Diving Instructors (PADI)}

Agency ini telah memiliki program yang selalu disosialisaskan dan diajarkan kepada calon wisatawan atau para instruktur yang akan mendapatkan sertifikat dari PADI. Program tersebut dinamakan 10 tips for divers to protect the ocean planet, yang meliputi:

a. Be a buoyancy expert

Biota baik hewan maupun tumbuhan yang berada di bawah laut merupakan makhluk hidup yang rapuh. Gesekan dari kamera bahkan sentuhan dari manusia akan sangat merusak dan membahayakan kelestariannya, sehingga para penyelam diharuskan dapat melakukan kegiatan selam dengan baik dan benar. Keterampilan dan teknik menyelam dan pengambilan foto bawah air harus tetap dijaga untuk menghindari kontak langsugn dengan lingkungan. Hal ini dapat dilakukan dengan selalu meneruskan pelatihan untuk menyempurnakan keahlian dalam melakukan kegiatan selam.

b. Be a role model

Penyelam-penyelam baru terus dilatih dan mendapatkan sertifikasi sesuai dengan tignkat keahlian masing-masing. Terlepas dari tingkat pengalaman dan keahlian yang dimiliki, agensi ini mengharapkan setiap penyelam yang disertifikasi dapat menjadi contoh bagi penyelam lain atau bahkan calon penyelam.

c. Take only photos - leave only bubbles

Semua yang ditemukan di bawah air merupakan makhluk hidup atau akan digunakan untuk hidup, jadi agensi ini memberikan peringatkan bahwa jika penyelam mengambil karang, cangkang atau binatang, maka akan mengganggu keseimbangan alam di bawah laut dan menambah penipisan tempat menyelam untuk generasi yang akan datang. Hal ini 
berarti akan mengganggu keberlangsungan objek wisata yagn ditawarkan.

d. Protect Underwater Life

Prinsip keempat ini memiliki arti bahwa calon penyelam ataupun penyelam agar tidak menyentuh, memberi makan, menangani, mengejar atau mengendarai apapun di bawah air. Tindakan ini akan menekan hewan, mengganggu habitat dan kebiasaan makan dan bereproduksi dari hewan, serta akan memprovokasi perilaku agresif hewan dan tumbuhan di bawah air.

e. Become a Debris Activist

Limbah yang ada di bawah air akan sangat mengganggu habitat dan mengancam kesehatan. Program ini menganjurkan untuk para penyelam agar sadar untuk melakukan upaya sekecil mungkin sehingga tidak meninggalkan limbah di bawah air.

f. Make Responsible Seafood Choices

Penangkapan ikan untuk digunakan sebagai sumber makanan manusia merupakan praktek yang banyak dilakukan. Sebagai konsumen yang ikut menjaga ekosistem bawah laut, memiliki peran yang sangat penting, yaitu memilih makan yang bersumber secara lestari. Tidak hanya berhenti sampai diri sendiri, kampanye untuk memilih sumber makanan ini dapat diberikan kepada orang lain termasuk restoran dan pemilik toko untuk melakukan hal yang sama.

g. Take Action

Penyelam scuba merupakan pendukung laut yang dibutuhkan untuk menjaga kelestarian ekosistem bawah laut. Program ini memberikan arahan agar para penyelam dapat menyampaikan ke masyakarat tentang pentingnya konservasi, melaporkan kerusakan-kerusakan yagn terjadi di bawah laut kepada pihak yang berwenang dan mengajak penyelam lainnya untuk melakukan perubahan, yaitu dengan melindungi ekosistem bawah laut saat melakukan penyelaman.

h. Be an Eco-tourist

Dianjurkan untuk membuat keputusan yang tepat saat memilih dan mengunjungi tujuan. Fasilitas yang didedikasikan untuk praktik bisnis sosial dan lingkungan yang bertanggung jawab termasuk konservasi air, pengurangan energi, pembuangan limbah yang tepat, penggunaan pelampung tambat dan penghormatan terhadap budaya, Undang-Undang dan peraturan setempat juga perlu diperhatikan.

i. Shrink Your Carbon Footprint
Pemanasan global dan pengasaman laut menjadikan ekosistem di seluruh bumi menjadi beresiko. Program ini menganjurkan agar para penyelam mengambil bagian dengan memahami jejak karbon yang ditinggalkan dan mencari cara untuk mengimbangi apa yang tidak dapat dihindari/dikurangi.

j. Give Back

Pentingnya investasi untuk melindungi planet bumi dan memberikan peluang menyelam untuk generasi yang akan dating, donasi sangat penting untuk diupayakan. Penggalangan dana ini mendorong tindakan dasar dan perubahan kebijakan yang diperlukan untuk memastikan planet laut yang bersih dan sehat.

(Jenkins, 2014).

\subsubsection{The National Association of Underwater Instructors (NAUI)}

Dalam menjalankan proses bisnisnya, NAUI menawarkan kepada masyarakat sebuah program untuk menjadi seorang penyelam yang mampu melindungi ekosistem. Program tersebut dinamakan NAUI Green Diver Initiative (GDI). Program ini dibentuk pada tahun 2010 oleh NAUI bekerjasama dengan Disney Worldwide Conservation Fund (DWCF), memberdayakan individu untuk melestarikan dan melestarikan planet laut. GDI terbuka untuk semua orang, penyelam dan non-penyelam dengan tujuan bersama untuk mengambil tindakan melindungi lingkungan. Pada tahun 2017, GDI bermitra dengan Center for Open Exploration (C4OE) melaksanakan sebuah program untuk melakukan survey dan pembersihan di Tampa Bay. Acara pembersihan ini merupakan salah satu dari sekian banyak kegiatan yang dilakukan dengan para penyelam NAUI. Kegiatan ini dilakukan untuk mengatasi pencemaran yang berada di bawah gelombang yang seringkali tidak diperhatikan karena tidak terlihat.

Kegiatan lain sebagai bentuk program GDI adalah penyelenggaraan Nerol Divers Xtreme Dive Center (XDC) di Zouk Mosbeh, Lebanon yang bekerjasama dengan Operation Big Blue Association (OBBA) yang merupakan organisasi non pemerintah Lebanon yang didedikasikan untuk melindungi dan memantau lingkungan pesisir dan laut, melakukan aktivitas di bawah air, serta pembersihan. Penyelam NAUI di Tampa, Florida, dengan Program Estuary Teluk Tampa, Kawasan Konservasi Tanah dan Tanah Hillsborough County, The Florida Aquarium, Brandon Scuba, dan Center for Open Exploration, bergabung dan memindahkan hampir 100 pon sampah berupa 70 pon sampah 
di sepanjang hamparan Seddon Channel Bay yang menutupi kira-kira 1.000 kaki di sepanjang dan sekitar 75 kaki dari tembok laut. NAUI mengajak para pemangku kepentingan untuk mengambil tindakan dalam melindungi dan melestarikan sumber daya air global bersamasama.

\subsubsection{Confédération Mondiale des Activités Subaquatiques (CMAS)}

Agensi ini menyusun dan menawarkan program yang peduli pada lingkungan dan ekosistem. Program tersebut berupa training yang dikhususkan untuk melestarikan budaya. Training ini diselenggarakan bekerjasama dengan pusat selam setempat dan dirancang unutk para olahragawan selam yang berminat dengan arkeologi bawah laut. Dalam pengantar teoritis, peserta akan mendapatkan wawasan tentang topik arkeologi bawah laut, dan kondisi konservasi khusus di bawah air. Pada bagian praktek, training ini memberikan kesempatan para pesertanya untuk menemukan berbagai situs budaya di taman bawah laut. Selain itu, juga diberikan pelajaran bagaiman harus berperilaku di monument bawah air dan apa yang dapat dilakukan jika menemukan objek yang menarik dari sejarah/arkeologi.

\section{KESIMPULAN}

Tanggapan 108 pelaku usaha terhadap persyaratan standar untuk wisata selam terbagi dalam aspek produk, pelayanan, dan pengelolaan. Untuk aspek pelayanan, didapatkan bahwa penyampaian informasi pelayanan termasuk didalamnya informasi pengantar, informasi selama penyediaan pelayanan dan informasi asuransi, merupakan hal utama yang harus dipenuhi oleh pelaku usaha. Faktor selanjutnya adalah keselamatan dan penanganan kesehatan konsumen. Pada aspek produk, peryaratan kompetensi untuk pemandu dan instruktur selam merupakaan hal utama yang harus diperhatikan oleh pelaku usaha. Faktor selanjutnya adalah kepemilikan peralatan permukaan sebagai pendukung keselamatan. Aspek produk yang terakhir adalah kepemilikan dari peralatan dan paket penyelaman. Aspek terakhir adalah aspek pengelolaan. Persyaratan dalam aspek pengelolaan yang harus dipenuhi oleh pelaku usaha adalah bentuk organisasi, akses layanan kesehatan, sumber daya manusia, dan sarana prasarana.

Riset ini juga menghasilkan analisa tekait faktor lingkungan dalam pengelolaan destinasi pariwisata. Konsep ekowisata mencakup konservasi, partisipasi, ekonomi, edukasi, dan wisata, sehingga riset ini menghasilkan indikator kinerja untuk destinasi dengan konsep ekowisata, yaitu 14 indikator untuk pengelolaan konservasi, 9 indikator untuk manfaat ekonomi, 6 indikator untuk memaksimalkan manfaat bagi masyarakat, pengunjung dan budaya serta meminimalkan dampak negatif, serta 12 indikator untuk manfaat bagi lingkungan dan meminimalkan dampak negatif.

Kesimpulan dari penelitian ini adalah menunjukkan seluruh responden telah mampu menerapkan peraturan menteri tentang standar usaha wisata selam. Peran pemerintah, masyarakat lokal dan wisatawan sangat diharapkan oleh industri wisata untuk mencapai tujuan keberlangsungan pengelolaan aset wisata.

\section{UCAPAN TERIMA KASIH}

Penulis mengucapkan terimakasih kepada pimpinan Badan Standardisasi Nasional (BSN) yang telah mengalokasikan anggaran untuk penelitian ini. Ucapak terimakasih juga diucapkan pada wakil dari Kementerian Pariwisata, pelaku usaha wisata selam, serta tim Puslitbang BSN yang telah berpartisipasi dalam penelitian ini.

\section{DAFTAR PUSTAKA}

Barker, N. H., \& Roberts, C. M. (2004). Scuba diver behaviour and the management of diving impacts on coral reefs. Biological Conservation, 120(4), 481-489.

Bentz, J., Lopes, F., Calado, H., \& Dearden, P. (2016). Understanding diver motivation and specialization for improved scuba management. Tourism in Marine Environments, 12(1), 35-49.

BNSP. (2009). Standar Kompetensi Kerja Nasional Indonesia Sektor Pariwisata Bidang Kepemanduan Wisata Selam. Jakarta

Choovanichchannon, C. (2015). Satisfaction in Thai Standard of Tourism Quality. Procedia-Social and Behavioral Sciences, 197, 2110-2114.

Clenney. TL \& Lassen, LF. (1996). Recreational scuba diving injuries. American Family Physician, 53(5):1761-1774.

Daely, K., Sinulingga, U., \& Manurung, A. (2013). Analisis Statistik Faktor-Faktor yang Mempengaruhi Indeks Prestasi Mahasiswa. Saintia Matematika, 1(5), 483-494.

Davis, D., \& Tisdell, C. (1995). Recreational scuba-diving and carrying capacity in 
marine protected areas. Ocean \& Coastal Management, 26(1), 19-40.

Epstein, N., Bak, R. P. M., \& Rinkevich, B. (2001). Strategies for gardening denuded coral reef areas: the applicability of using different types of coral material for reef restoration. Restoration Ecology, 9(4), $432-442$.

GSTC. (2013). GSTC destination criteria. ww.gstcouncil.org/gstc-criteria/gstcdestination-criteria. Diakses terakhir pada tanggal 3 februari 2018

Giyanto, et al. (2017). Status terumbu karang Indonesia 2017. Jakarta: Pusat Penelitian Oseanografi - LIPI

Guraidhoo, K. (2017). Sri Lankan tourist dies during dive. https://maldivestimes.com/sri-lankantourist-dies-during-dive/

Hawkins, J. P., \& Roberts, C. M. (1992). Effects of recreational SCUBA diving on forereef slope communities of coral reefs. Biological Conservation, 62(3), 171-178.

Ismayanti. (2010). Pengantar Pariwisata. PT Grasindo : Jakarta

ISO. (2017). ISO 24803:2017 - Recreational diving services - requirements for recreational diving providers. Jenewa

Jenkins, A. (2004) 10 Tips for Divers to Protect the Ocean Planet. http://www.padi.com. Diakses tanggal 29 Januari 2018.

Kementerian Pariwisata. (2014). Statistik Profil Wisatawan Mancanegara. Jakarta

Kementerian Pariwisata dan Ekonomi Kreatif. (2014). Peraturan Menteri Pariwisata dan Ekonomi Kreatif Nomor 15 Tahun 2014 Standar Usaha Wisata Selam. Jakarta

Kementerian Pariwisata. (2016). Peraturan Menteri Pariwisata Nomor 7 Tahun 2016 - Pedoman Penyelenggaraan Wisata Selam Rekreasi. Jakarta

Kementerian Pendayagunaan Aparatur Negara dan Reformasi Birokrasi. (2014). Peraturan Menteri Nomor 15 Tahun 2014 - Pedoman Standar Pelayanan. Jakarta

Kunzmann, A., \& Efendi, Y. (1994). Kerusakan terumbu karang di perairan sepanjang pantai Sumatera Barat. J. Penelitian Perikanan Laut, 91, 48-56.

Lippmann, J. M., \& Pearn, J. H. (2012). Snorkelling-related deaths in Australia, 1994-2006. Medical journal of Australia, 197(4),230-232. doi: $10.5694 / \mathrm{mja1} 1.10988$
Luthfi, O.M. (2016). Konservasi terumbu karang di Pulau Sempu menggunakan konsep taman karang. Journal Of Innovation And Applied Technology. 2(1), 210-216.

Musa, G., \& Dimmock, K. (2012). Scuba diving tourism: introduction to special issue. Tourism in Marine Environments, 8(1-2), 1-5.

Newton, H. B. (2001). Neurologic complications of scuba diving. American family physician, 63(11), 2211-2218.

Oehms, O \& Vitriani, D. (2016). Global Suistainable Tourism Council (GSTC) Guidelines on Lombok Destination Assesment. Suistainable Regional Economic Growth and Investment Programme (SREGIP). Jakarta.

Priyono, A. (2014). Strategi Pengembangan Industri Pariwisata Bahari. Disampaikan pada Kongres Maritim Indonesia tanggal 23-24 September 2014 di Yogyakarta. Diakses pada tanggal 29 Maret 2018. Tersedia http://maritim.wg.ugm.ac.id/wpcontent/uploads/2014/09/AgusPriyono_Kebijakan-Industri-PariwisataBahari.pdf

Republik Indonesia. (2009). Undang-Undang Republik Indonesia Nomor 10 Tahun 2009 tentang Kepariwisataan. Jakarta.

Santoso, A.D., \& Kardono (2008). Teknologi Konservasi dan Rehabilitasi Terumbu Karang. Jurnal Teknologi Lingkungan, 9(3), 221-226.

Siaran Pers. (2016). Saatnya Peduli Keselamatan Saat Menyelam. Diakses pada 5 Januari 2018 pada https://lampung.antaranews.com/berita/2 87512/saatnya-peduli-keselamatan-saatmenyelam.

Straughan, E. R. (2012). Touched by water: the body in scuba diving. Emotion, Space and Society, 5(1), 19-26.

TIES.(1990). Ecotourism Definition. http://www.ecotourism.org/book/ecotouris m-definition.

Tinumbia, R. P., Nugroho, A. M., \& Ramdlani, S. (2016). Penerapan Prinsip Ekowisata pada Perancangan Fasilitas Pengelolaan Ekosistem Terumbu Karang di Gili Trawangan. Jurnal Mahasiswa Jurusan Arsitektur, 4(1), 1-8

-----, (2009). Undang-Undang Nomor 10 Tahun 2009. Kepariwisataan. Jakarta

UNWTO. (2016). UNWTO Annual Report World Tourism Organization. Published by the 
World Tourism Organization (UNWTO), Madrid, Spain.

UNEP \& WTO.(2005). Making Tourism More Sustainable (A Guide for Policy Makers). UNEP Deveision of Technology, Industry and Economics-France; World Tourism organization-Spain.
Yuliani, W. (2016). Pengelolaan Ekosistem Terumbu Karang oleh Masyarakat di Kawasan Lhokseudu Kecamatan Leupung Kabupaten Aceh Besar. Jurnal Ilmiah Mahasiswa Pendidikan Biologi, 1(1),

1-9. 
